\title{
Retrospective analysis of selected aspects of public blood transfusion service activities as a starting point for assessment of the status of transfusion medicine in Poland. Part 2: Demographic characteristics of the population who donated blood/blood components for clinical use in the period 1997-2017
}

\author{
Agata Mikołowska®, Jolanta Antoniewicz-Papis® \\ Institute of Hematology and Transfusion Medicine, Warsaw, Poland
}

\begin{abstract}
Summary
Background. Demographic changes in Poland, mainly population ageing and the health status of the general population, have direct impact on the number of donors/donations, and therefore on the possibility of securing appropriate amounts of blood and blood components for clinical use. The health status of the population is largely affected by diseases responsible for donor deferral. Recent years have witnessed increment in the percentage of temporary donor deferrals due to various types of allergies, civilization diseases, drug intake as well as frequent travels to areas threatened with new and emerging pathogens likely to be transmitted through blood transfusion.

The first and crucial step towards safe blood/blood components and recipient safety is rigorous donor qualification.
\end{abstract}

The structure of the population of Polish donors is not homogeneous, moreover has undergone changes during the period under investigation. It is therefore worthwhile to analyze the dynamics of changes in the number and structure of the donor population to determine the direction and intensity of the phenomenon both in spatial and temporal terms. Equally important is identification of the possible causes.

The study aim is to present the demographic characteristics of the donor population found eligible for donation and donated blood/blood components for clinical purposes in the years 1997-2017.

Material and methods: Records for the period 1997-2017 included about 11 million voluntary donors of blood/blood components for clinical use and 31.000 remunerated donors. Most study analyses were based on data from the 2005-2017 as not all relevant data were available for the period 1997-2004 period.

In the 2005-2017 period donations were collected from over $87 \%$ of donors who reported to all RBTCs. Slight year-to-year differences were observed (from approx. 85\% to 94\%). Donations were mainly collected from voluntary un-remunerated donors (99.8\%).

Adres do korespondencji: dr n. med. Agata Mikołowska, Instytut Hematologii i Transfuzjologii, ul. I. Gandhi 14, 02-776 Warszawa, tel.: (22) 34963 91, e-mail: amikolowska@ihit.waw.pl

Translation: mgr Krystyna Dudziak

This article is available in open access under Creative Common Attribution-Non-Commercial-No Derivatives 4.0 International (CC BY-NC-ND 4.0) license, allowing to download articles and share them with others as long as they credit the authors and the publisher, but without permission to change them in any way or use them commercially. 
The largest number of donors eligible for donation was reported in 2005 (94.1\%), and the smallest in 2015 (84.2\%).

Deferred from donation were $22.0 \%$ of women willing to donate and only $9.2 \%$ of men. Similar tendency was observed for each year of the study period.

Results: Study outcome shows reversal of trends for donor age groups; currently most donors are recruited from the 25-44 age category while several years back it was the youngest age group.

For many years now actions promoting voluntary blood donation have been ongoing in Poland. Study-outcome shows big differences in numbers of blood donors reporting to individual RBTCs. Despite many years of nationwide voluntary blood donation promoting campaigns, it is the regional policy of donor acquisition and retention that counts most.

Conclusions: A problem that sooner or later will have to be faced by most countries (Poland included) is the decline in the number of working-age population.

The demographic structure of the population within areas of activity of each RBTC should be subjected to in depth analysis and include the characteristic microeconomic and demographic conditions as well as macroeconomic and demographic conditions for neighbor regions and the country as a whole. Decisions regarding marketing strategy could then be taken.

The research outcome may be a valuable source of information to support effective management of donor service and effective planning of marketing strategy targeted at donors and prospective blood donors.

\section{Key words: demographic changes, blood donors, blood transfusion service, regional blood transfusion centers}

J. Transf. Med. 2021; 14: 93-110

\section{Introduction}

The primary goal of the modern blood transfusion service worldwide is provision of adequate amounts of safe blood components for clinical use as well as raw material for manufacture of blood products. A well- functioning blood transfusion service is also an extremely important precondition for health-care efficiency. The critical success factor here is to secure a sufficient flow of motivated, voluntary, unremunerated blood donors [1].

Demographic changes ongoing in our country, mainly population ageing, have direct impact on the number of donors/donations, and consequently on securing appropriate amounts of blood/blood components for clinical use. The observed changes are related not only to the decline in birth rates. Other factors that limit the population of potential donors involve migration of young people as well as the modern lifestyle that affects physical and mental health of the general population.

The health condition of the population in general has significant impact on the population of blood donors. The number of donors and donations is closely related to the country's demographic situation as well as the health condition of the population in terms of diseases responsible for donor deferral [2]. Recent years have witnessed increment in the percentage of temporary deferrals related to various types of allergies, civilization diseases, drug intake as well as frequent travels to areas threatened with new pathogens that might be transmitted through blood transfusion and pose an epidemiological threat [3].

The Epidemiology of Allergic Diseases in Poland (ECAP) - survey demonstrated a steep rise in the incidence of allergic diseases in recent years, especially bronchial asthma and allergic rhinitis (hay fever). The latest ECAP data show these allergies to occur in approximately $30-40 \%$ of the Polish population. The problem is now so serious that experts are talking about an "allergy epidemic". The European Academy of Allergy and Clinical Immunology (EAACI) predicts that by 2025 as many as $50 \%$ of the European population will struggle with some type of allergy. By 2050, according to World Allergy Organization (WAO) forecasts, there will be 4 million people around the world suffering from allergy. In Poland, the number of people suffering from allergies doubles on average every 10 years [4]. 
An interesting and significant indicator of national health and condition of the health-care system are changes in the dynamics of sickness absenteeism. In 2018, 21.5 million medical certificates of temporary incapacity due to own illness for a total of 277.3 million days were registered in the Medical Certification Register of the Comprehensive IT System of the Social Insurance Institution (KSI ZUS). As compared to 2017, this is an increase by approx. $0.5 \%$ (21.4 million) and a decrease in the total number of days by approx. $1.4 \%$ (288.3 million). In 2018, medical certificates were mainly issued to people aged 30-39 (over 5.6 million), also $20-29$ and 40-49 (4.3 million in each group respectively). The most common causes of absence were: osteoarticular disorders (15.4\%), injuries and poisoning (13.8\%) as well as respiratory diseases $(13.5 \%)$. Mental and nervous system disorders were quite a large category $(8.0 \%$ and $7.6 \%$, respectively) $[5,6]$.

Another serious problem affecting the general health condition of the population is overweight and obesity, the latter defined as the risk factor for occurrence of many chronic conditions including cardiovascular diseases, several cancers, type 2 diabetes as well as premature mortality. The results of the 2017 Global Burden of Disease Study point to obesity as one of the most serious total risk factors for diseases in the Polish population [7].

Most recent data on the prevalence of overweight and obesity in Poland are from the autumn 2018 study of the National Institute of Public Health - National Institute of Hygiene (NIZP-PZH). The study was conducted as part of the National Health Program on a random sample of 3,000 Polish citizens representative in terms of age, sex and place of residence. The study outcome revealed excessive body weight in $58.8 \%$ of men and $41.1 \%$ of women; obesity in $11.2 \%$ and $11.3 \%$, respectively [8].

All the diseases mentioned above are criteria for deferral from blood/blood component donation. During recruitment of blood donors, BTCs actively promote pro-health behavior/activities, rational diet, avoidance of risky behavior (including risky sexual behavior) as well as regular check-ups. All the above contribute to upgrading the public health care system.

From the point of view of public health, shaping of pro-health behavior is of utmost importance, as risky behavior may generate health and social problems and negatively impact on the quality of blood and blood components, and ultimately on recipient safety.
Rigorous donor qualification is the first and extremely important step in obtaining safe blood and blood components, and ensuring recipient safety.

It is known for a fact that the structure of the population of Polish donors is not homogeneous and has been undergoing changes during the period under investigation (1997-2017).

In light of the above, it seemed worthwhile to analyze the dynamics of changes in the number and structure of the donor population who actually donated blood/blood components and also to determine the direction and intensity of the phenomenon both in spatial and temporal terms. It is extremely important to identify the possible causes of the ongoing changes. This is the second work in the series of publications presenting selected aspects of the activity of Polish blood transfusion service the aim of which is to assess the status of transfusion medicine in Poland. The first work in the series was devoted to the demographic characteristics of the donor population reporting for blood donation to the Regional Blood Transfusion Centers (RBTC) in the years 2005-2017 (no matter whether the donation was finalized or not) [9].

The next work in the series will be devoted to the characteristics of donations collected from donors in the years 1997-2017.

\section{Aim}

The study aim is to present the demographic characteristics of the donor population found eligible for blood donation and donated blood/blood components for clinical purposes in the years 1997-2017.

\section{Materials and methods}

Research was based on data forwarded to the Institute of Hematology and Transfusion Medicine (IHTM) by 21 RBTCs.

The raw material for statistical analysis consisted of reports on RBTC activities sent every year to IHTM.

The following tools were used for data preparation and analyses: Microsoft Access, Microsoft Excel and Microsoft Power Business Intelligence (Power BI). A detailed description of the statistical material and methods was presented in the first publication [9].

\section{Results}

Characteristics of donors found eligible for donation of blood and blood components for clinical purposes are presented below. 


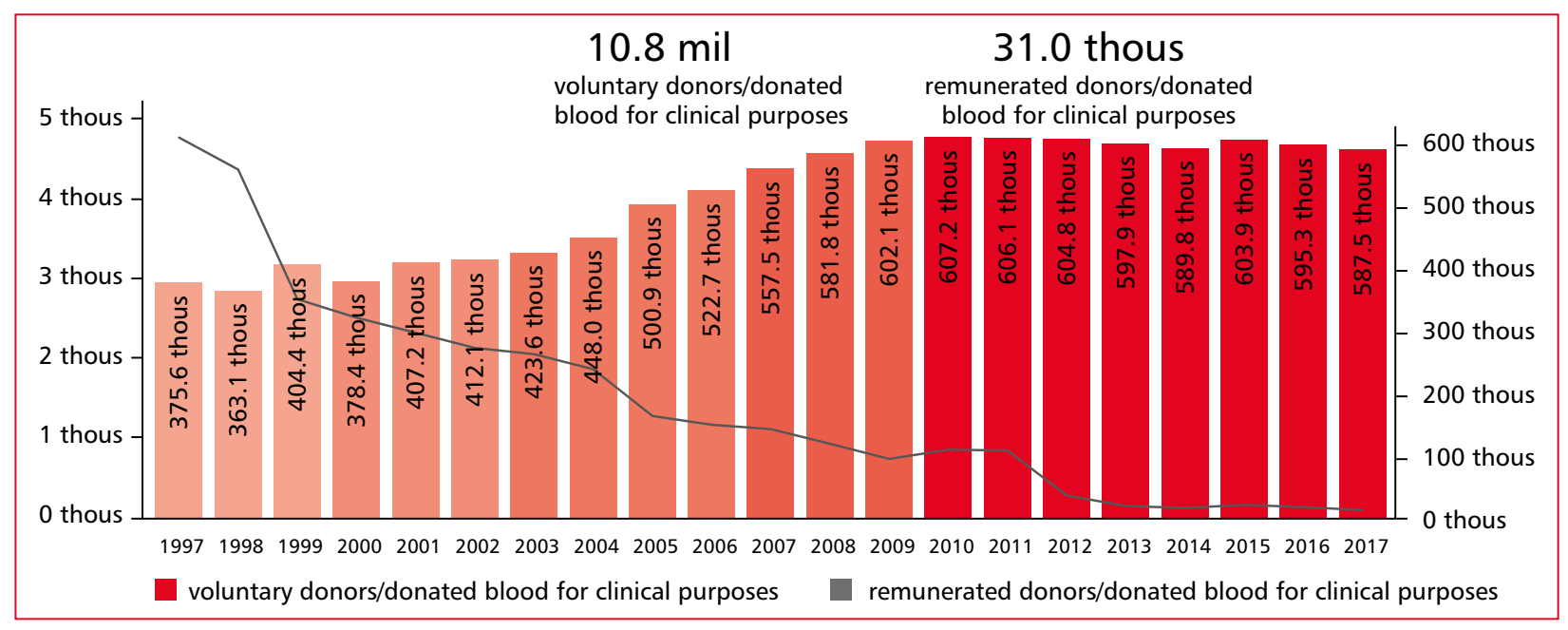

Figure 1. Voluntary and remunerated donors who donated blood/blood components for clinical purposes (1997-2017)

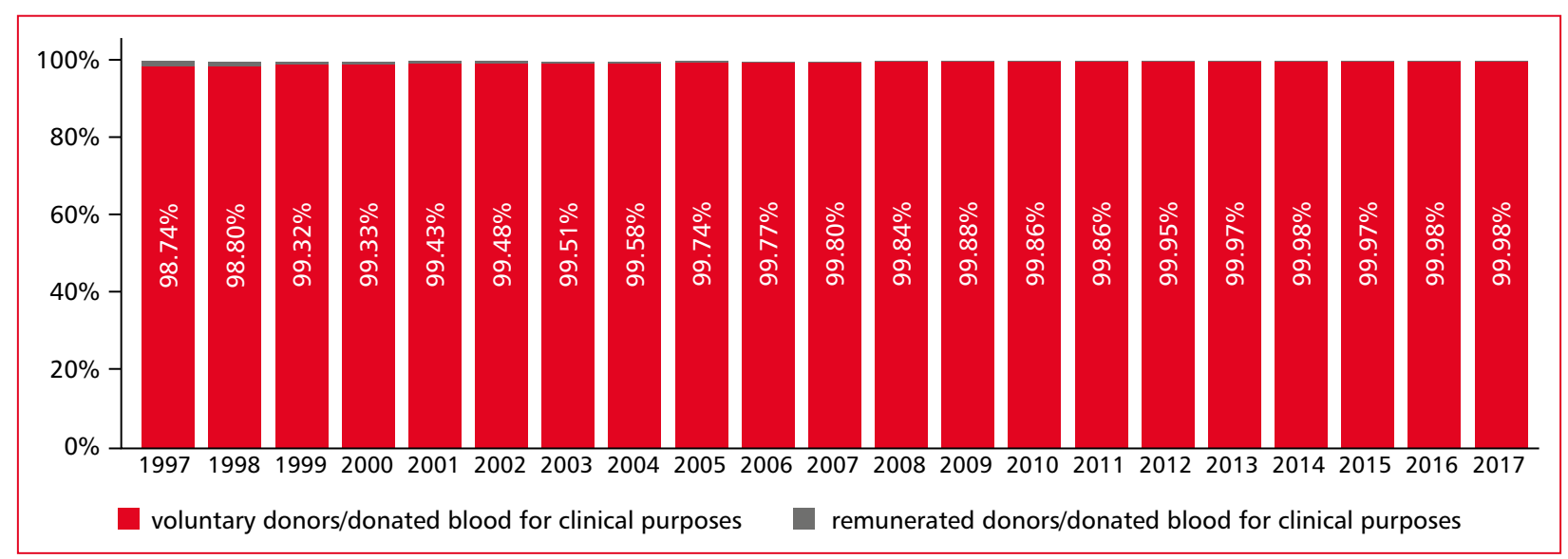

Figure 2. Percentage of voluntary and remunerated donors who donated blood/ blood components for clinical purposes (1997-2017)

According to available data, the total number of voluntary donors who donated blood/blood components for clinical purposes in 1997-2017 amounted to approximately 11 million; the total number of remunerated donors was estimated at only 31,000 . The number of voluntary donors had grown steadily and in the recent years has reached an number of approximately 600,000 per year. In the recent years, the number of remunerated donors is only 100-150 per year (Fig. 1).

In consecutive years of the 1997-2017 period, the percentage of voluntary donors was almost $100 \%$ (Fig. 2).

In order to compare the numbers of donors who did donate blood/blood components with those who reported to the RBTC declaring willingness to donate, data for the 2005-2017 period was allocated for further analysis, as no data was collected for the 1997-2004 period. 99.8\% of all donors who donated blood/blood components for clinical purposes were voluntary while remunerated donors were only $0.2 \%$ (Fig. 3 ).

\section{Donors who donated blood/blood components and donors not eligible for blood donation}

In the period under analysis, $87.2 \%$ of all voluntary donors who reported to the RBTCs were found eligible for donation (7.6 million); in $12.8 \%$ of cases (1.1 million) donations were not finalized (Fig. 4).

The year-to-year analysis demonstrates that the percentage of voluntary donors who donated blood/blood components oscillated within the range of $85-94 \%$. The largest number of donors found eligible for donation was in 2005 (94.1\%), and the smallest in 2015 (84.2\%) (Fig. 5). 


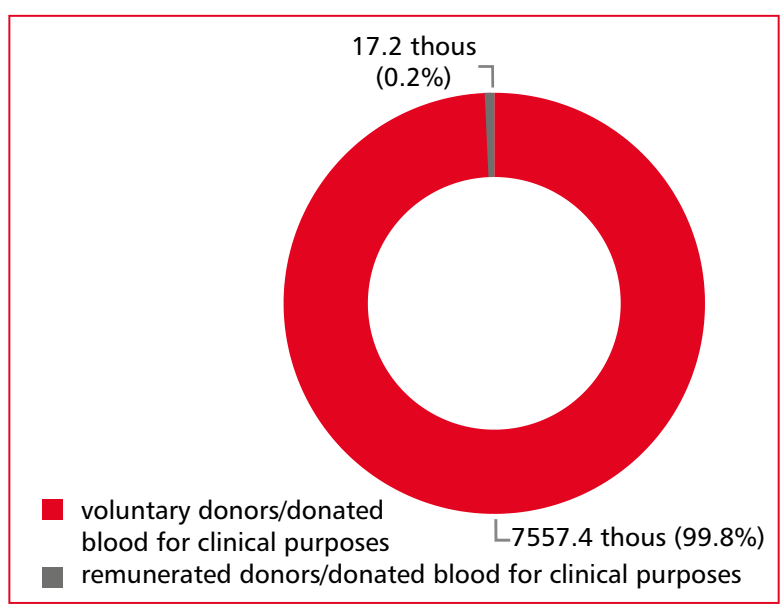

Figure 3. Voluntary and remunerated donors who donated blood/blood components for clinical purposes; cumulative data for 2005-2017

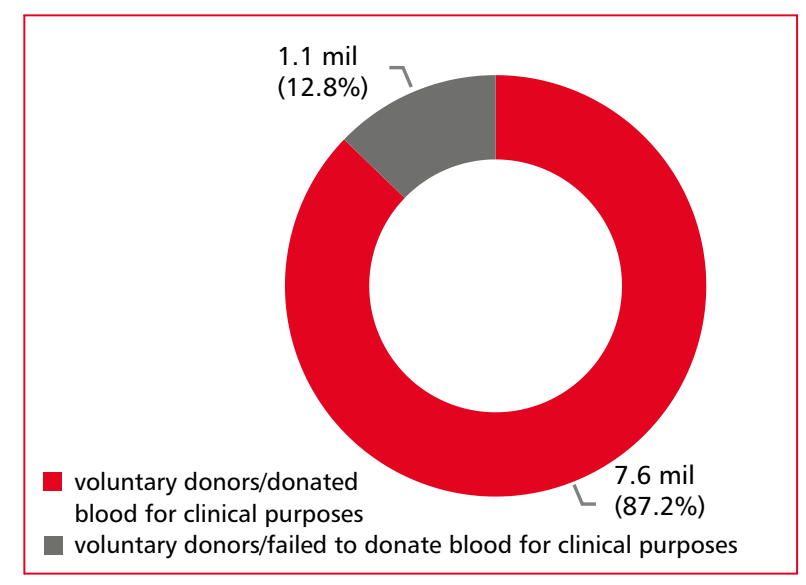

Figure 4. Percentage of donors who donated blood for clinical purposes and those who failed to finalize donation, cumulative data 2005-2017

A similar tendency was observed in individual RBTCs. The largest number of donors found eligible for donation was reported in Szczecin $(91.8 \%)$, while the lowest in Lublin $(79.2 \%)$ (Fig. 6).

\section{Men and women}

Donations were collected from $78 \%$ of women who reported to donate blood/blood components; approximately $1 / 4^{\text {th }}$ of the female population willing to donate did not finalize donation. In the case of men, only $9.2 \%$ were deferred. Figure 7 presents data for women and men found eligible for donation and those who did not finalize donation.

The year-to-year analysis of the percentage of women/men found eligible for donation and deferred from donation demonstrates that male donors finalized donation more frequently and the tendency continued throughout the study period (Fig. 8).

The reports for individual RBTCs also show that men were more frequently found eligible for donation than women (Fig. 9).

Within the total of 7.5 million donors found eligible for donation, 5.6 million (73.8\%) were men while women were less than 2 million (26.2\%) (Fig. 10).

\section{Donor age}

For the purpose of analysis, data with regard to donor age was divided into two groups: data for 2005-2010 (Group 1) and data for 2011-2017 (Group 2).

\section{Group 1}

The first group comprised donors divided into 4 age categories: $18-30,31-45,46-65$ years, and one group of "under 18 and above 65 ". The latter age group was disregarded in the analysis as it was by far the least numerous. Figures 11 and 12 present the number of voluntary donors who donated blood/blood components (women and men respectively), broken down into age groups. By far the most numerous group were donors aged 18-30 (both men and women), while the least numerous category were donors aged $46-65$.

The figures below present the percentage of women and men who donated blood/ blood components for clinical purposes broken down into age groups versus donors who failed to donate. The data demonstrates that most women deferrals (medical reasons or self-deferral) occurred in the youngest age group, i.e. 18-30 (17.4\%), followed by $31-45(15.8 \%)$ and $46-65(14.5 \%)$. The highest number of deferrals for men was recorded in the 46-65 (8.3\%) and 18-30 (8.0\%) age groups, while the lowest was observed in the $31-45$ (7.8\%) age group (Figs. 13-15).

\section{Group 2}

The second group included donors divided into 5 age categories: $18-24,25-44,45-65$, under 18 and over the age of 65 . The last two age groups were disregarded in the analysis as they were by far the least numerous. Data shows that most female donors were in the 18-24 age group (the exception is 2017 , when most female donors were recruited from the 25-44 age group).The smallest number of female donors was recorded in the 45-65 age group. In the case of men, donors in the 25-44 age group 


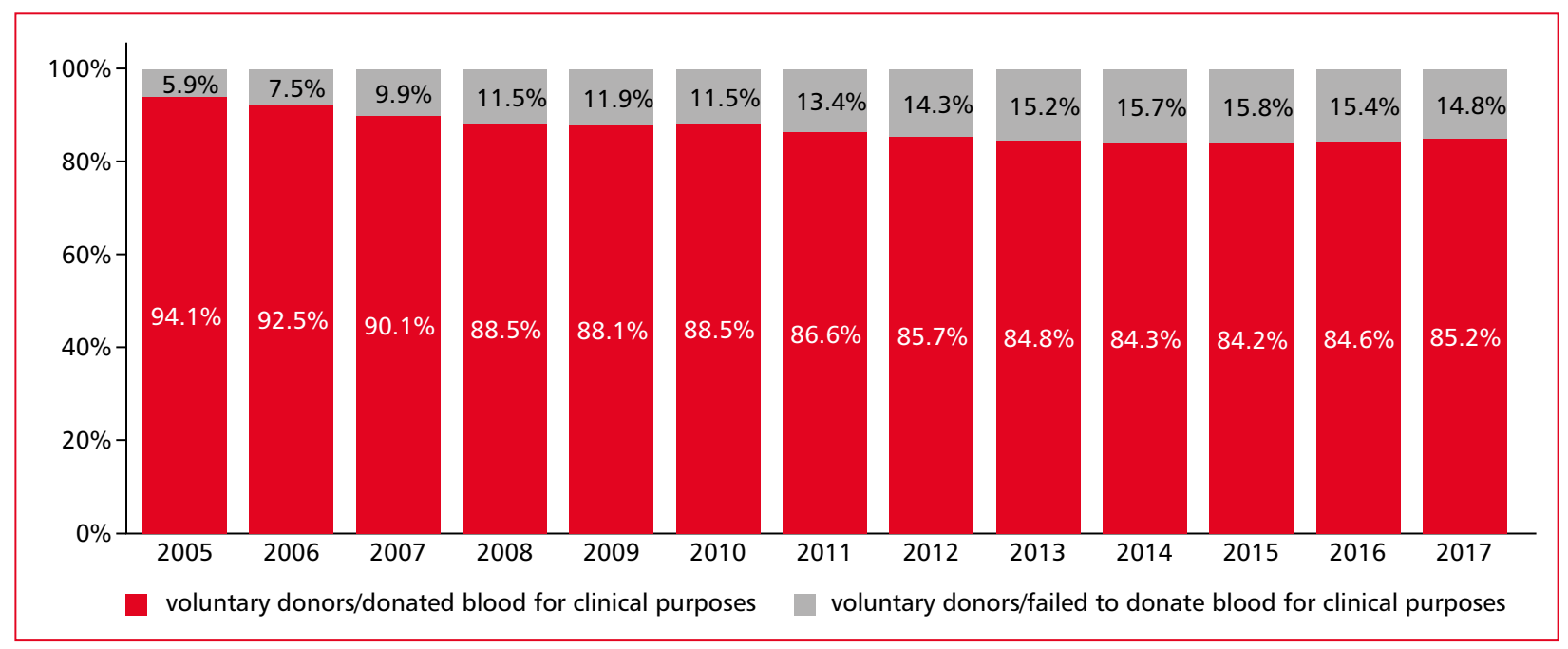

Figure 5. Percentage of donors who donated blood/blood components and those who did not finalize donation (2005-2017)

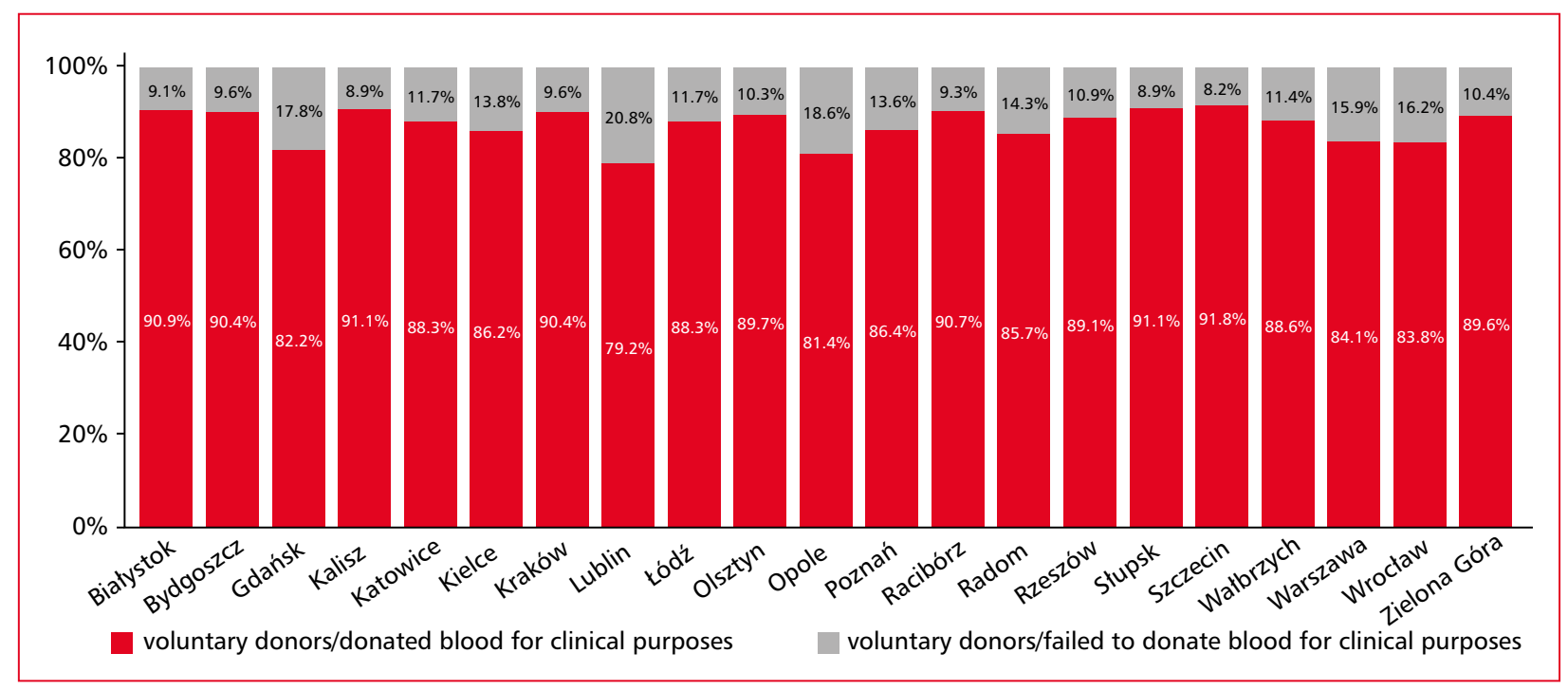

Figure 6. Percentage of donors who donated blood/blood components and those who did not finalize donation, broken down into RBTCs, cumulative data (2005-2017)

most often donated blood/blood components (with the exception of 2005 when the largest number of donors was recruited from the youngest age group - 18-24). Like for women, the lowest number of donors was reported in the $46-65$ age group (Figs. 16 and 17).

The figures below present the percentage of women and men who donated blood/ blood components for clinical purposes broken down into age groups versus donors who failed to donate.

Data shows that the highest percentage of women and men who failed to donate was recorded in the youngest age group and amounted to over
$28 \%$ and almost $12 \%$, respectively. However, it should be noted that the percentage of men in the youngest group who failed to donate was merely $0.7 \%$ higher than in the $45-65$ age group (Figs. 18-20).

The figure below presents summary of data referring to numbers of donors in age categories in Group 1 and Group 2. As already mentioned, the data demonstrates that in Group 1, the most numerous donor population was in the 18-30 age category, while in Group 2 the trend changed and the most numerous group were donors in the 25-44 age category (Fig. 21). 


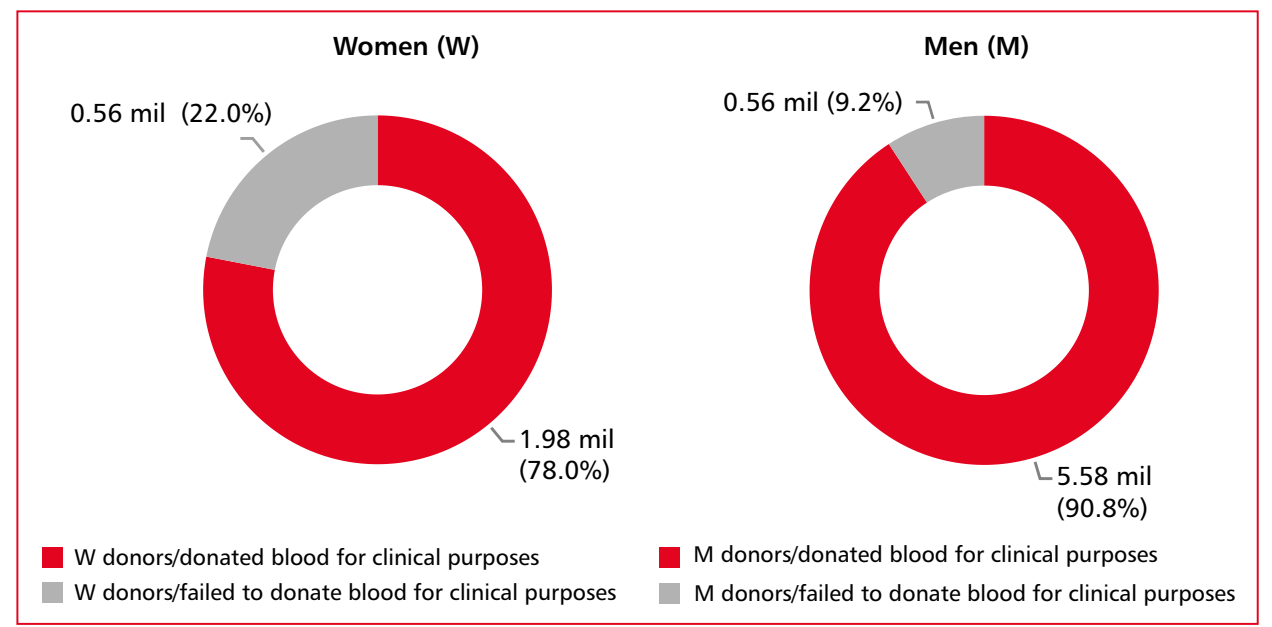

Figure 7. Percentage of women and men eligible for donation vs those who did not finalize donation, cumulative data 2005-2017

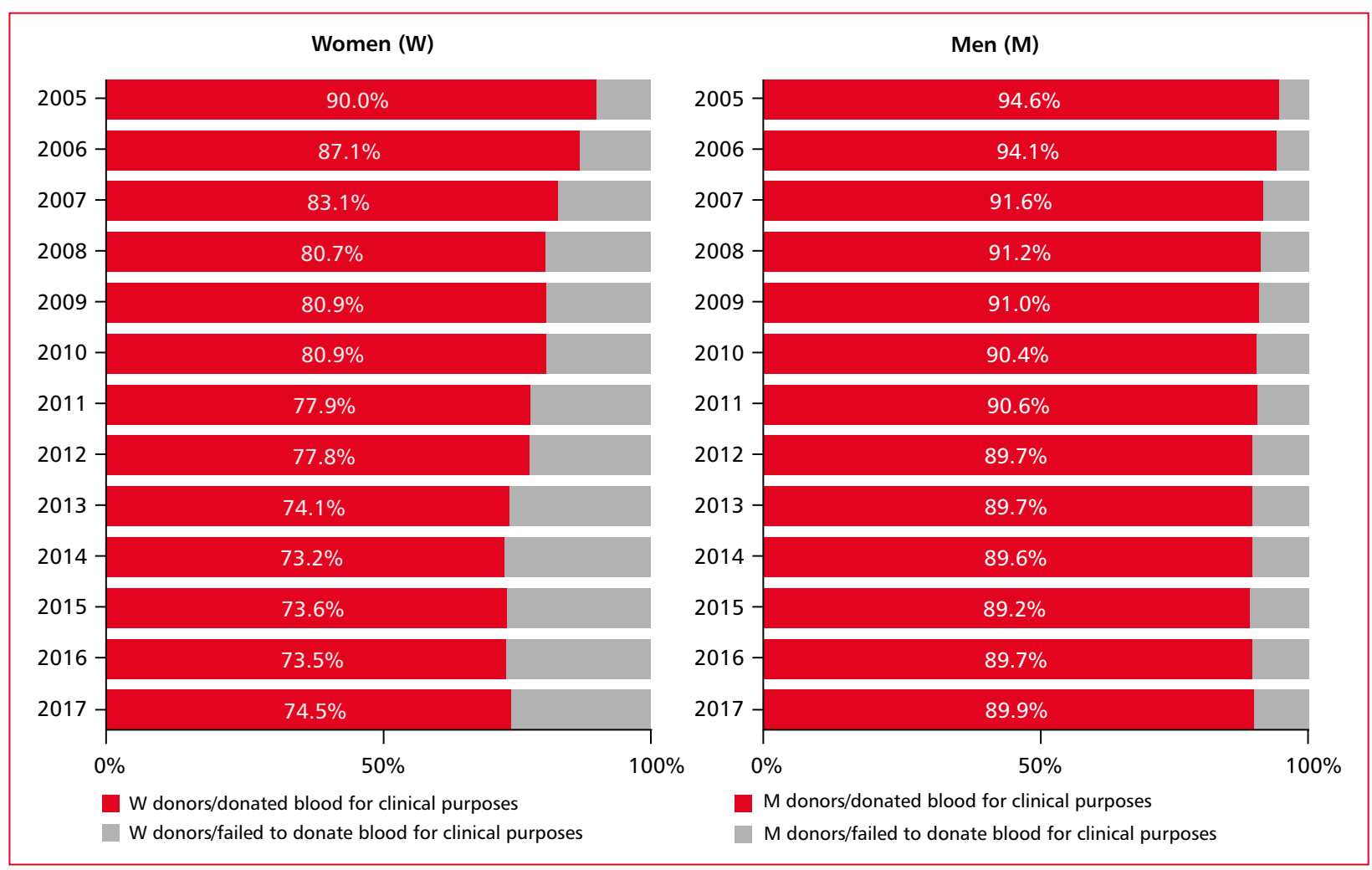

Figure 8. Percentage of women and men who donated blood/blood components vs those who did not finalize donation (2005-2017)

\section{Discussion}

The presented study analysis indicates that the donor population in Poland is not homogenous in terms of structure. Moreover, several significant changes were determined over the period under analysis.
In the period 2005-2017, donations were collected from over $87 \%$ of donors who reported to RBTCs with the intention of donating blood. Slight year-to-year differences were observed (from approx. 85\% to 94\%). Donations were mostly collected from voluntary un-remunerated donors $(99.8 \%)$ as recommended by global and European 


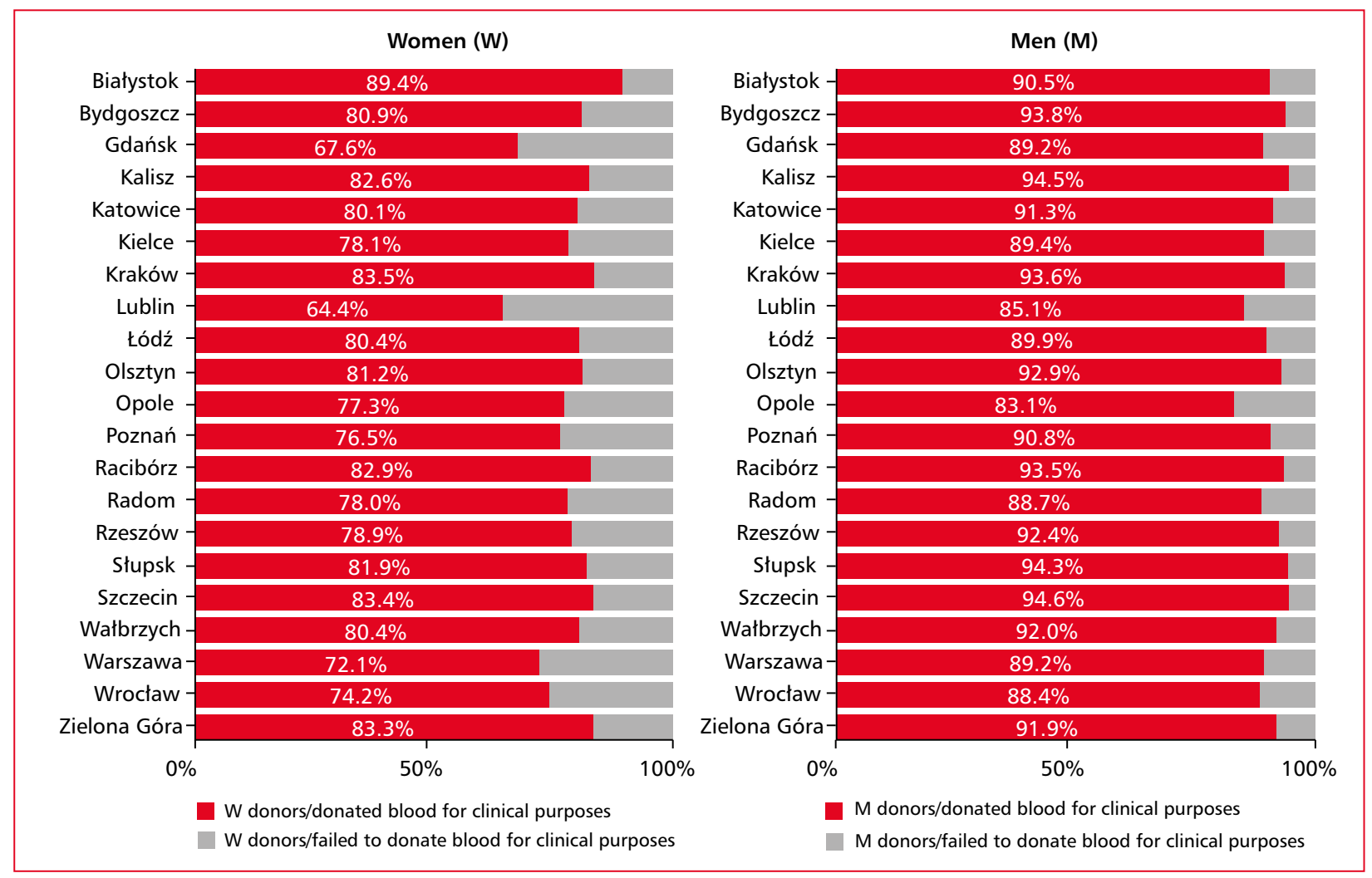

Figure 9. Percentage of women and men eligible for donation and deferred from donating blood/blood components broken down into RBTCs, cumulative data 2005-2017

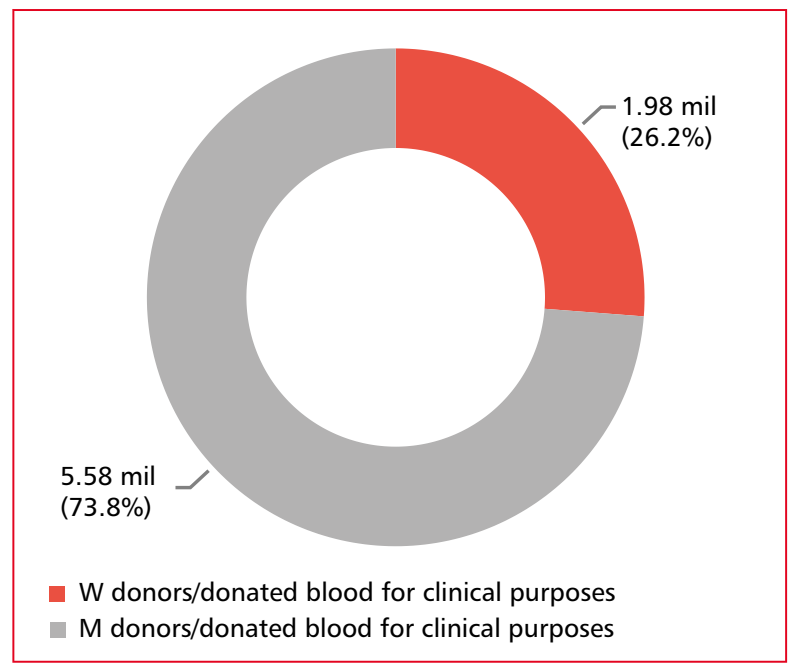

Figure 10. Percentage of women and men who donated blood/blood components for clinical use, cumulative data 2005-2017

guidelines according to which blood transfusion service in every country should depend entirely on un-remunerated voluntary donation of blood and blood components. Blood/blood components were not collected from $>12 \%$ of persons who declared willingness to donate (data from all RBTCs during the whole period under analysis). Most likely reasons for not finalizing donations were either medical deferral (temporary or permanent) or self-deferral, the former being more frequent. The frequency and cause for medical deferral were not the subject of this analysis. In this study, attention was focused on the change in the number of donors deferred from donation in individual RBTCs over the 2005-2017 period. According to study results this number is growing every year. In $2005,5.9 \%$ of donors were deferred from donating blood but over the five year-period under analysis the percentage increased from over $14 \%$ in 2012 to almost $16 \%$ in 2017. Differences were also observed among RBTCs. In the whole period under analysis, the greatest number of donors were found eligible for donation in RBTC in Szczecin (almost 92\%), while the smallest number in RBTC in Lublin (slightly above $79 \%$ ). In all RBTCs women were deferred from blood donation much more frequently than men.

Among the possible reasons for differences in the number of deferrals among RBTCs, some are undoubtedly related to the health condition of 


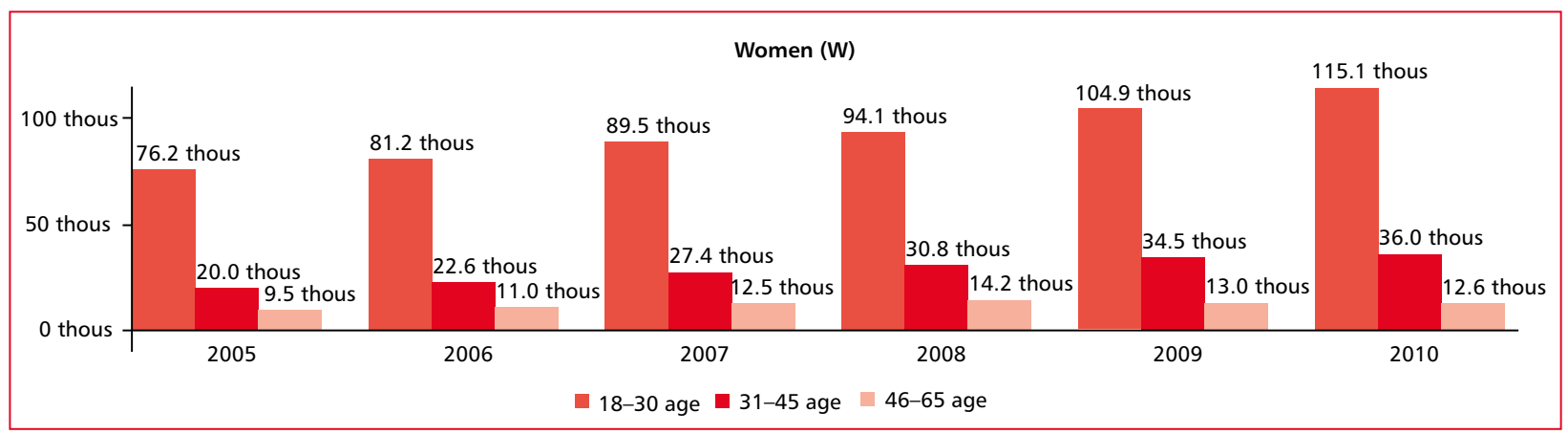

Figure 11. Women in different age groups (group 1) (2005-2010)

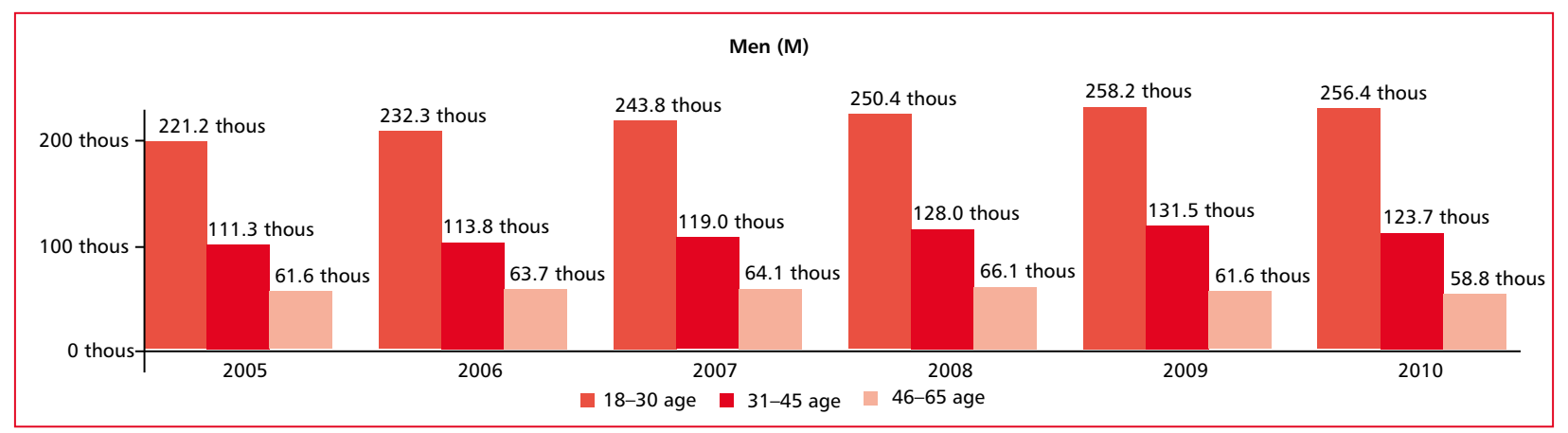

Figure 12. Men in different age groups (group 1) (2005-2010)

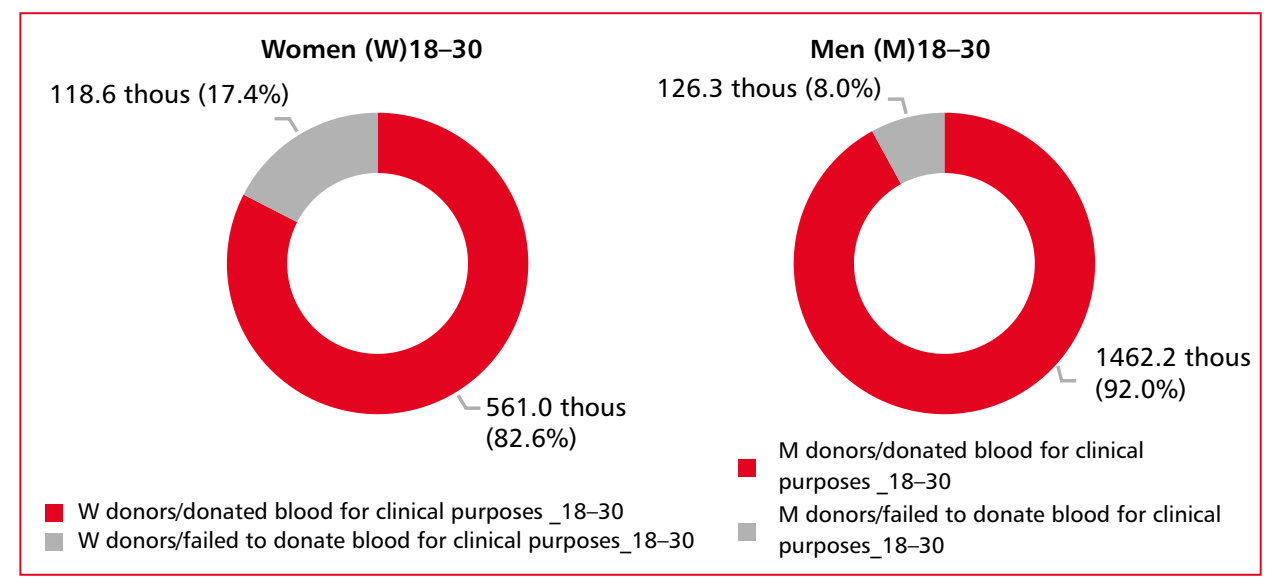

Figure 13. Percentage of women and men aged 18-30 eligible for and deferred from donation, cumulative data 2005-2010

the population of the region as well as the health condition of the Polish population in general. The recent years have witnessed an increasing tendency for temporary deferral due to i.a. various types of allergies, civilization diseases, and drug consumption [3].
It seemed reasonable to perform a detailed analysis of data regarding the numbers and reasons for deferral as well as the place of imposing deferral (RBTC headquarters, local collection site or mobile collection). It also seemed worthwhile to identify as many reasons for deferral as possible 


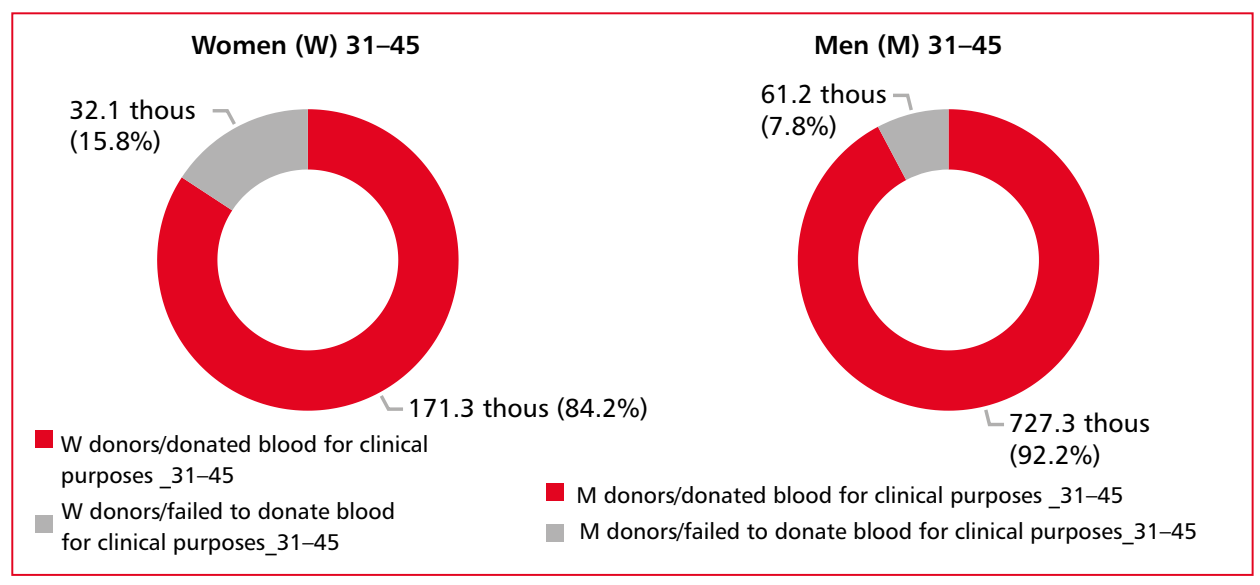

Figure 14. Percentage of women and men aged 31-45 eligible for and deferred from donation, cumulative data 2005-2010

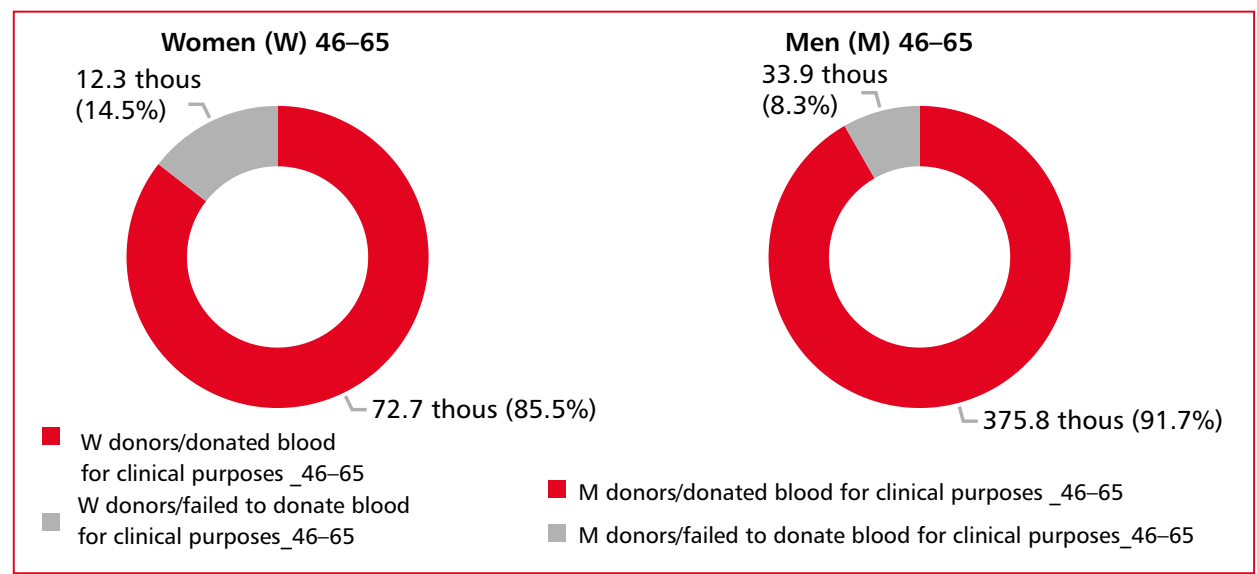

Figure 15. Percentage of women and men aged 46-65 eligible for and deferred from donation, cumulative data 2005-2010

in order to explain the significant differences that occur, despite uniform, strictly defined donor eligibility criteria. Moreover, the analysis of the most frequent reasons for temporary and permanent deferral among blood donors may provide valuable information on the health condition of these potentially most healthy representatives of the general society.

In addition, the study outcome indicates reverse of the trends in donor age groups; several years back the highest number of donors was recruited from the youngest age group while currently the most numerous is the 25-44 age category.

A similar tendency was described by Wittock et al. in a cross-country and periodical publication which provides answers to the question "Who donates?" The data for the study come from the Eurobarometer database, and the analysis covered
28 member countries of the European Union in the years 1994, 2002, 2009 and 2014. The results clearly indicate that over the period significant changes occurred in the frequency of blood donation in specific age groups. In $1994,21.1 \%$ of donors were recruited from the youngest age group (18-29); in 2014 - only $14.2 \%$. The percentage of donors in the 30-44 age category also decreased (from $39.1 \%$ in 1994 to $30.9 \%$ in 2014 ), while in the $45-54$ and 55-65 age categories increase was recorded (from $23.0 \%$ to $24.9 \%$ and from $16.7 \%$ to $30.1 \%$ respectively) [10].

The reversal of trends and the decline in the number of donors from the youngest age category is reason for great concern. Undoubtedly, more effective ways of reaching new donors, especially the youngest ones, should be sought. Rapid technological advancement, especially mobile com- 


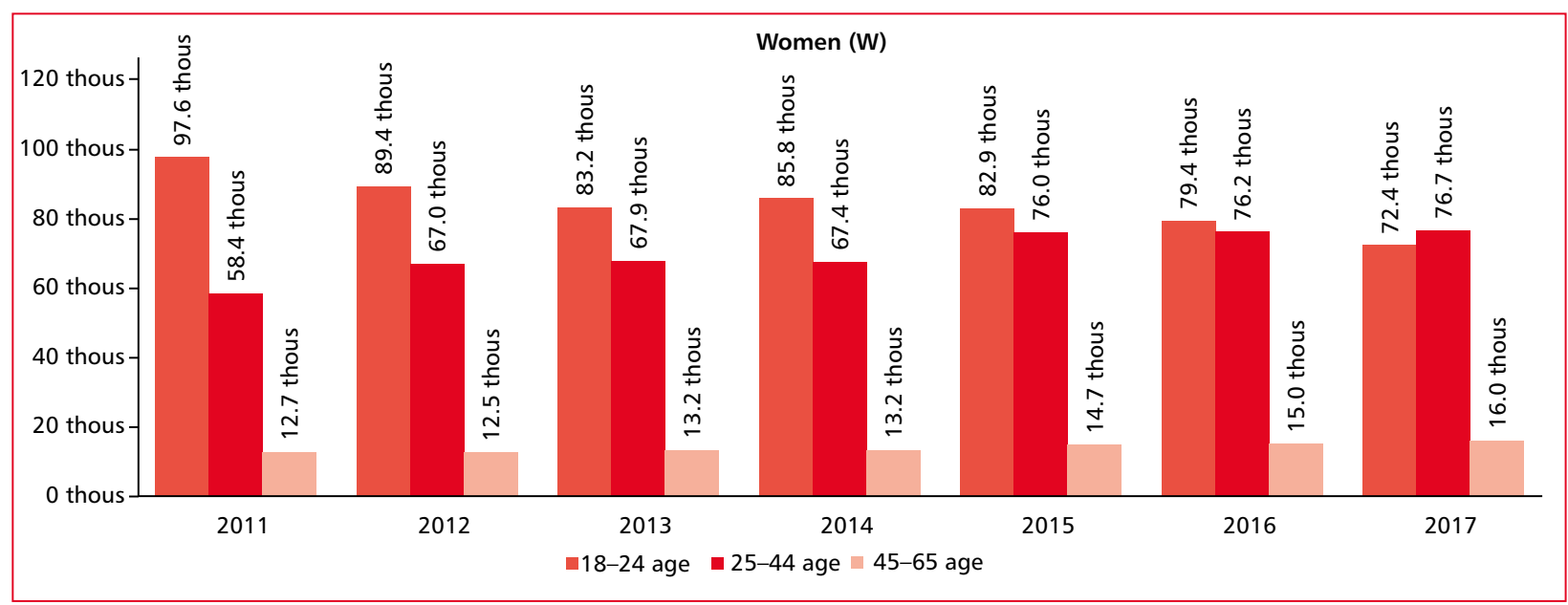

Figure 16. Women in each age group (group 2) (2011-2017)

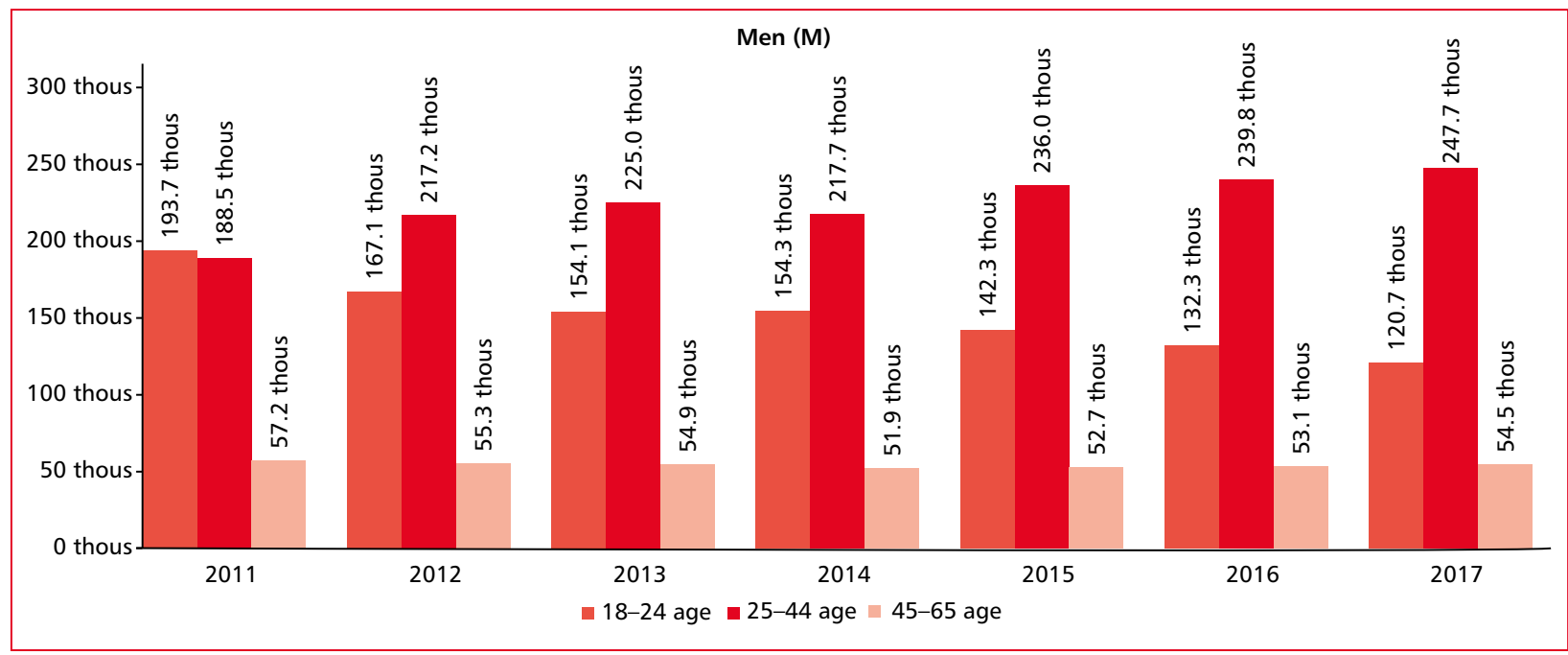

Figure 17. Men in each age group (group 2) (2011-2017)

munication may contribute to radically improve new-donor recruitment and help to retain the already active donors. Social media are one of the means of communicating with donors, especially the youngest ones. Facebook is an example of a social media network used to connect with others, to create "topic" groups . Under "Voluntary Blood Donor" dozens of comments have been posted. As of June 7, 2021, the "Honorary Blood Donor" group is most numerous and brings together over 48.2 thousand users. It is a valuable source of information on donor satisfaction with the visit to RBTC or problems experienced during donation. Donor entries are a good source of information for RBTCs staff and support them in upgrading the quality of donor service. On the other hand, large groups of social media users represents a huge potential for promotion of voluntary blood donation.

Numerous studies and publications investigate the use of mobile communication technologies in upgrading donor recruitment and retention. In a 2016 study, Yuan et al. sent out e-mail invitations to blood donors in a large metropolitan area to participate in an online survey. The survey was designed to assess their readiness and interest level for a blood donation mobile application. A total of 982 respondents of various age groups were surveyed, among whom $87.3 \%$ declared having ready access to smart phones. Among the donors in the study group, e-mail was chosen by $(62.1 \%)$ as the preferred method when contacted by the blood center, followed by SMS (10.1\%). Overall, $67.7 \%$ of respondents indicated that they were likely to use 


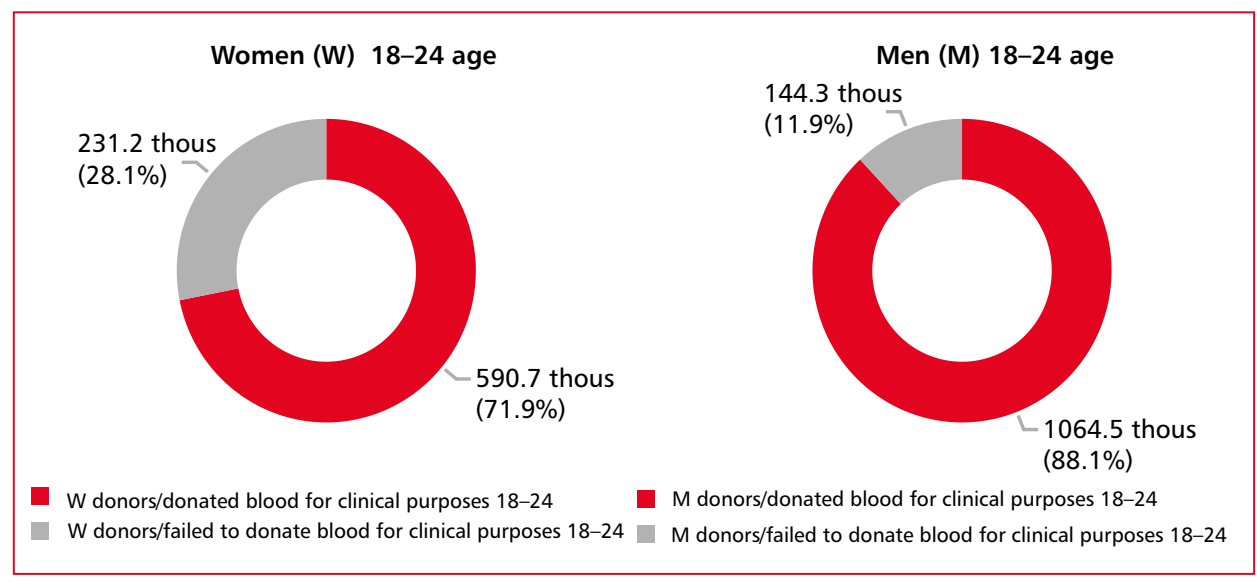

Figure 18. Percentage of women and men aged 18-24 eligible for and deferred from donation, cumulative data 2011-2017

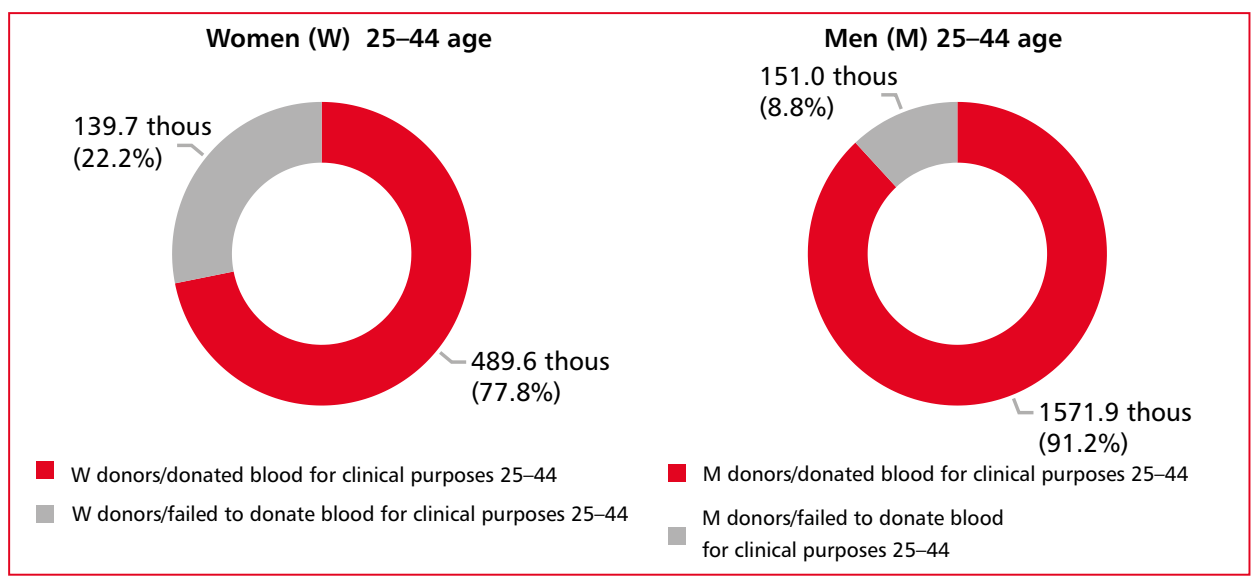

Figure 19. Percentage of women and men aged 25-44 eligible for and deferred from donation, cumulative data 2011-2017

a blood donation mobile application. Likelihood did not significantly differ by sex or ethnicity and the impact of educational level was limited. However, donors over 45 years of age were less likely than younger donors to use the app ( $\mathrm{p}=0.001)$, and multiple donors with at least 5 lifetime donations were more likely than less frequent donors to use such an application $(\mathrm{p}=0.02)$. Donors who previously made donation appointments via phone or website were equally likely to use such an application. The results of the study demonstrate that donors are open to using new mobile communication technologies, including mobile applications to manage their donations [11].

Equally important is to take on measures to increase the number of women willing to donate blood/blood components. Our analysis indicates that throughout the entire study period, the popula- tion of male donors was significantly higher than of women (7:3). Additionally, women were more likely to be deferred; for many years now the deferral ratio for women was about 7: 3 versus 9: 1 (for men).

There are many factors that contribute to this state of things. Legal regulations for one; women are allowed to donate whole blood up to 4 times a year, men - up to 6 while the interval between donations cannot be shorter than 8 weeks ${ }^{1}$. Moreover, women are more likely to be temporarily deferred from donation due to pregnancy, recent childbirth or miscarriage, breastfeeding, menstruation, low body weight $(<50 \mathrm{~kg})$, low hemoglobin concentration or iron deficiency. Although imposed out of concern for donor safety, each deferral (even

\footnotetext{
${ }^{1}$ Regulation of the Minister of Health of September 11, 2017 on the conditions for collecting blood from candidates for blood donors and blood donors (Dz.U. 2017 poz. 1741)
} 


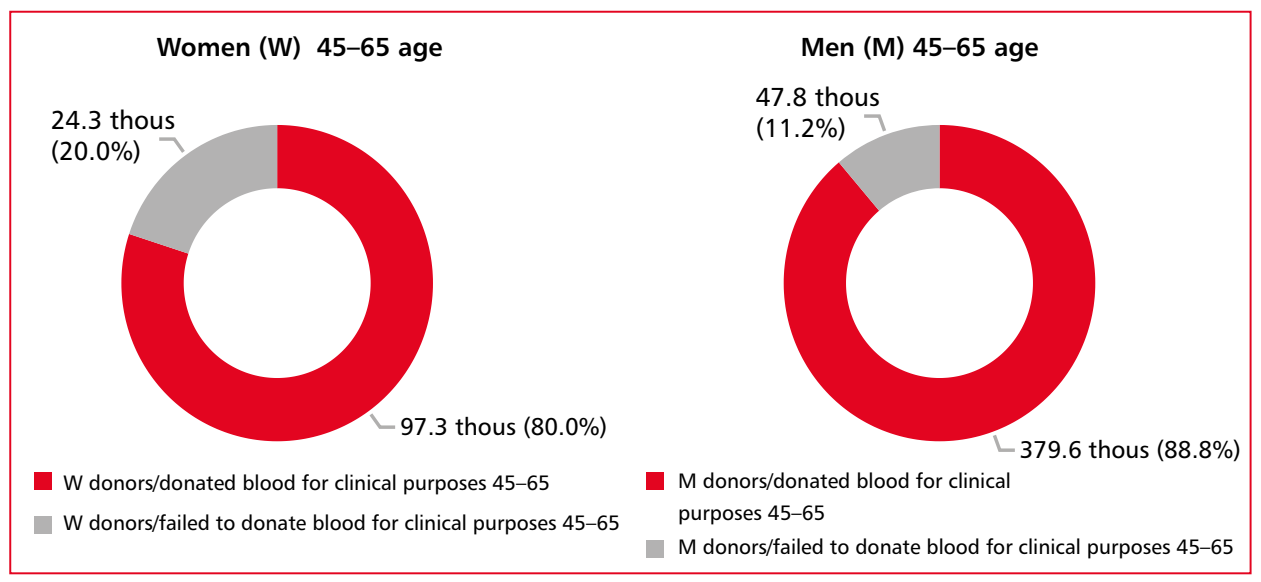

Figure 20. Percentage of women and men aged 45-65 eligible for and deferred from donation, cumulative data 2011-2017

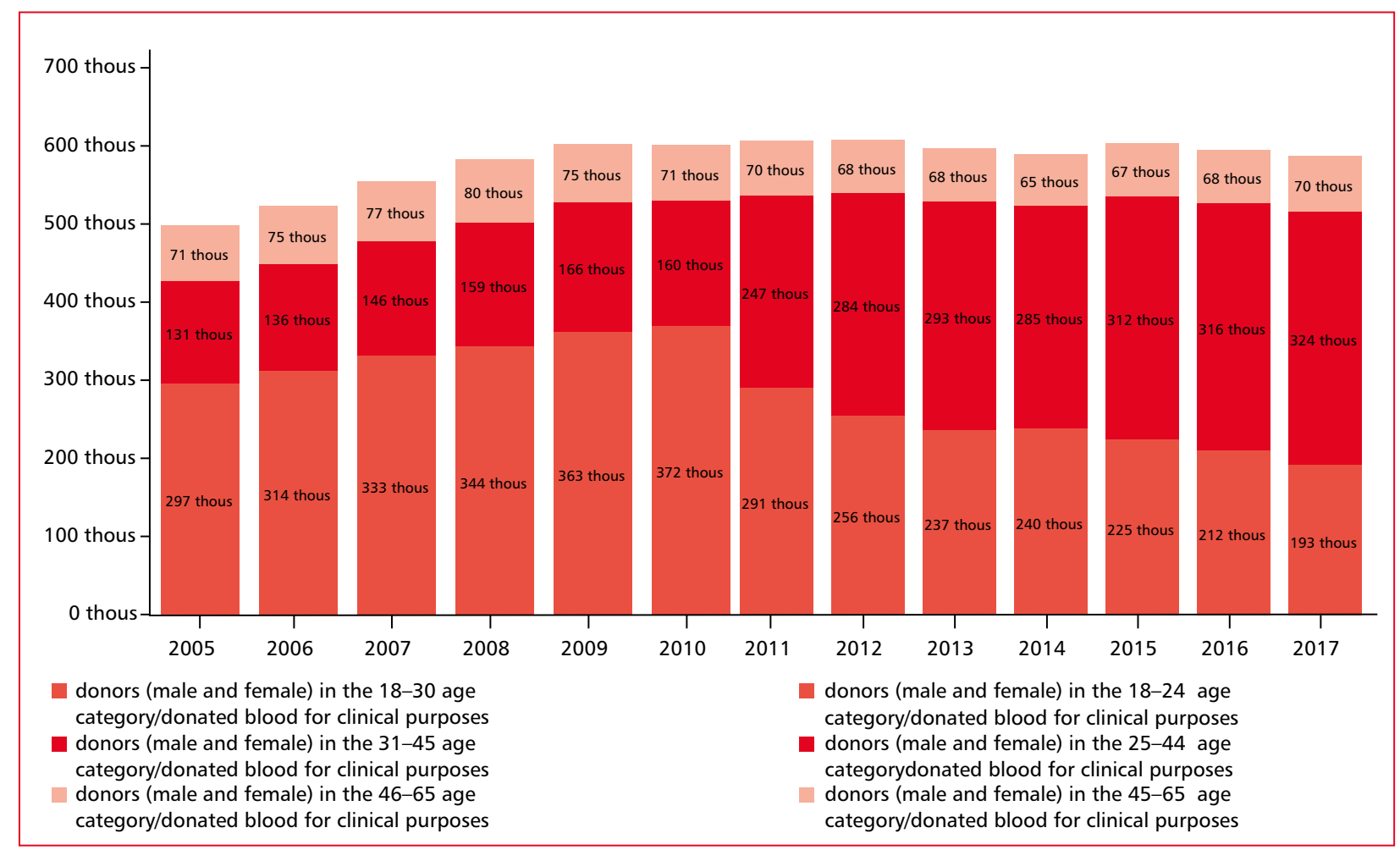

Figure 21. Comparison of donors who donated blood/blood components (group 1 and group 2) broken down into age groups, 2005-2017

temporary) stirs emotions and negatively impacts on future donor return. Research studies show that women have a more emotional attitude to deferral; at the same time they are more willing to donate for altruistic reasons. Additionally, women more often express anxiety with regard to blood donation and the possible donation-related adverse events and reactions $[10,12]$. The situation in Poland is in line with the global trends, however it is advisable to take a closer look at the factors that demotivate Polish women from donating blood as well as to undertake measures to expand the number of women in the population of donors. Identification of the reasons why women less often decide to donate may help to plan a more effective marketing strategy, including promotion of voluntary blood donation targeted at women and more educational campaigns focused on specific topics. The problem may not 
only be of medical or legal nature but may also result from insufficient information. In light of the current state of knowledge, women who were pregnant or transfusion recipients must be deferred or found eligible to donate only selected blood components because of the risk of immunization with HLA antigens which may put recipients at risk of transfusion related acute lung injury (TRALI) [13, 14].

It is very important to take on effective measures to persuade people to donate blood for the first time and to motivate donors to make regular and repeat donations. Undoubtedly, multiple donors ensure greater safety for the entire health care system as their decision to donate is more conscious and less spontaneous. In this group of donors infectious diseases are less frequent and so is risky behavior therefore the risk of transmission of infectious agents with donated blood is potentially the lowest. For this reason, marketing activities and campaigns promoting voluntary blood donation should be concentrated not only on attracting new donors, but also on encouraging people to donate blood on a regular basis. For this purpose, it is necessary to investigate the determinants of the willingness to donate blood. Research on the subject is going on worldwide. Huis in 't Veld et al. conducted a cross-country research aimed at describing the determinants of blood donation willingness in the European Union with the assumption that the readiness to donate depends on personal characteristics, beliefs and motivations, as well as on the cultural context. The aim of the study was to investigate whether the willingness to donate blood varies across European populations and if so, to explain the variability in terms of factors at individual and national level. The study was part of the 2014 round of the country-comparative survey, collected on behalf of the European Commission. The study sample consisted of 27,868 participants from $28 \mathrm{EU}$ Member States interviewed for the readiness to donate, personal motivation and incentives. Some respondents $(2.8 \%)$ refused to answer the question about their donation history and the willingness to donate blood. They were excluded from the study sample. Respondents in the age range of 15-70 were included because the authors were interested in the answers of only those who declared willingness or would soon be able to donate blood; people aged $>70$ years $(17.5 \%)$ were excluded from the sample. The study sample subjected to analysis $(\mathrm{n}=22,348)$. The results of the study demonstrated that $37.9 \%$ $(\mathrm{n}=8,471)$ of all respondents had already donated blood, $6,434(76 \%)$ of which were willing to donate again. Among 13,877 participants who had never donated blood, 7.814 (56.3\%) declared readiness to become blood donors. It was demonstrated that $>60 \%$ of study participants from the majority of EU countries (with the exception of Portugal, Malta, the Czech Republic, Slovakia, Hungary and the Balkan countries) declared willingness to donate blood in the future; the values ranged from $41.9 \%$ in Slovakia to $80.1 \%$ in Sweden; $63 \%$ of Polish respondents declared readiness to donate blood in the future. The study revealed that on the EU territory there are large groups of underinformed people who may be regarded as potential donors. The authors indicate that in the current demographic situation young men seem to be the main target group as they can donate blood more often than women. It was also found that respondents who were already blood donors with children were more willing to donate blood, which indicates that partnership and parenthood strengthen the sense of social responsibility and altruistic attitudes. In the donor populations under survey (eg. in the Netherlands) there were very few single young people which is indicative of the need to implement new recruitment strategies and measures to reach this particular target group. Social media were pointed out as one the possible recruitment paths. For development of effective and personalized recruitment strategies, the authors clearly emphasize the necessity of concentrating on factors both motivating and demotivating potential donors, as these can be shaped unlike factors such as gender and age. It is also advisable to improve educational strategies to increase overall confidence in blood transfusion service and motivate people to donate blood, especially in countries with low trust in transfusion therapy. In all countries the number of participants who clearly indicated money motivation was very low. The authors therefore suggest that in individual countries attention should be directed at educational and recruitment strategies to increase general awareness regarding blood safety and reasons of blood shortages rather than on material incentives [15].

Topics related to motivating blood donors were also studied by another group of scientists. In 2020, Fosgaard et al. published a manuscript in Transfusion under an intriguing title "Can text messages save lives? A field experiment on blood donor motivation". The idea was to send text messages to blood donors when their donation has helped a patient. The studies were large scale $(\mathrm{n}=20,365)$ and included Danish blood donors (Copenhagen region) randomly divided into two 
groups; one group received the SMS, the other did not. Study outcome demonstrated that the messages increased subsequent donations by $3.6 \%$ compared with donors who did not get SMS; the campaign proved more effective among plasma donors $(\mathrm{p}=0.003)$ than whole blood donors $(\mathrm{p}=$ 0.554). It was also shown that optimizing the time of day when the SMS were sent increased the effect substantially; SMS sent in the evening were much more effective than messages sent in the morning or afternoon. This type of SMS campaign has already been implemented in blood banks in Denmark (South Jutland) as well as in countries such as: Australia (Brisbane and New South Wales), Ireland, Sweden (Dalarna and Stockholm) and the United Kingdom [16]. The experiment confirmed that computer systems and electronic tools create new opportunities of reaching blood donors for more effective motivation to subsequent donations.

Martín-Santana et al. used a different approach. A total of 2,383 non-donors were enrolled in the study $(\mathrm{n}=2,383)$. The aim was to identify the motivating and demotivating factors that influence the decision to donate blood for the first time. To this end, a survey was conducted among Spanish citizens of both sexes older than 18 years. It turned out that in the study population of "non-donors" there were more women (74.3\%) than men $(25.7 \%)$. Most respondents were below 36 years (68.3\%), had higher education $(60.4 \%)$, were employed $(57.0 \%)$ with monthly income $<2.000$ EUR. The study group was divided into 6 clusters according to barriers and motivations. It turned out that the decision to donate blood for the first time is influenced by many intrinsic and extrinsic factors and is not easy to make. Marketing strategies addressed to each group separately were then designed [17].

For many years now actions promoting voluntary blood donation have been ongoing in Poland. The aim is to spread knowledge and convey the importance of blood therapy as well as to motivate society to donate blood. Such actions are best illustrated by health policy program for consecutive years ensuring the selfsufficiency of the Republic of Poland in blood and blood components, the last edition of which is "Ensuring the self-sufficiency of the Republic of Poland in blood and blood components for the years 2021-2026". The general aim of the program is to ensure national self-sufficiency in blood and blood components, while $2 / 5$ specific objectives are directed at increasing social awareness with regard to voluntary blood donation and healthy life style of blood donors. The activities are primarily aimed at retaining a constant number of conscious and responsible donors of blood and blood components. The action is targeted at: adult citizens, school children and high school students, employers and entrepreneurs within the framework of corporate social responsibility, medical entities and diagnostic laboratories, as well as clubs and associations working for voluntary blood donation. As part of this task, nationwide promotional and educational activities are undertaken to retain current donors but also to encourage interest in voluntary blood donation for potential donors [18].

This study-analysis indicates large differences in numbers of blood donors reporting to individual RBTCs. This means that despite many years of nationwide campaigns promoting voluntary blood donation, it is the regional policy of donor acquisition and retention that still counts most. In some RBTCs (Racibórz) promotional activities are extremely effective as the numbers of people reporting to donate blood increase year-to-year. It would therefore seem advisable for RBTCs to exchange experience and good practices related to promotion of voluntary blood donation and donor recruitment to increase the number of donors throughout the country.

The decline in the working-age population is a problem that sooner or later will have to be faced by most countries including Poland. The demographic situation in individual regions of Poland is diversified. The data published by the Central Statistical Office (GUS) indicate that for many years the highest percentage of people aged $\geq 65$ years has been recorded in the Eódzkie and Świętokrzyskie provinces (województwo), the lowest - in the Warmińsko-Mazurskie province. The statistics does not apply to residents of rural areas; the highest numbers of elderly people are recorded in Podlaskie (18.0\%), and the lowest in Pomorskie provinces (11.3\%). Long-term GUS forecasts are that in 2030 the Swiętokrzyskie, Opolskie and Łódzkie provinces will be inhabited by $1 / 4$ of the population aged $\geq 65$; the highest increment of elderly people (by $7.7 \%$ as compared to 2017 ) will be noted in the Warmińsko-Mazurskie province [8]. Of utmost importance is therefore an in depth analysis of the demographic structure of the population within the area of activity of each RBTC. This area of activity does not always cover the area of the province so demographic analysis at the level of the district (powiat) is called for. The analysis should include the microeconomic and demographic conditions characteristic for the region, as well as macroeconomic and demographic conditions for 
neighbor regions and the whole country. A decision on further marketing strategy can then be made. It is also extremely important to retain the largest possible number of regular donors. For this purpose, it is advisable for each RBTC to design and regularly disseminate donor satisfaction surveys. The process of data acquisition and analysis will be more effective if RBTCs rely on IT mechanisms. The results of such research is a valuable source of information to indicate the areas of activity that are appreciated by donors, and those that require upgrading or change. They also support effective management of donor service and contribute to more effective planning of marketing strategy targeted at donors and prospective blood donors.

Effective marketing and promotion for blood donation has been described at length in the publication of W. Drozd [12]. The author presents topics related to social marketing in blood donation, the value and importance of communication with donors and the role of marketing communication for donor recruitment in Poland. The publication is undoubtedly an important contribution to discussion on how to use social marketing for effective recruitment of blood donors.

Effective donor service is another topic widely discussed in recent literature. Scientists worldwide rely on various evaluation methods to investigate the level of donor satisfaction. They also use modern methods and tools often based on big-data analyses to upgrade work in blood banks and the quality standards of donor service. As early as 2010, Testik et al. used data mining for discovering both daily and hourly donor arrival patterns at the Hacettepe University Hospital's Blood Center (Ankara, Turkey). They found that long waiting time is one of the frequently mentioned disturbances of the blood donation process. They assumed that donor service can be much improved with shorter waiting time and adaptive workforce. Study data covered a 3 year-period (January 1, 2005 - December 31, 2007) and was obtained from the hospital ICT database. A total of 84,094 records was analyzed (one record $=$ one donor visit). In many blood centers there are no fixed appointments for collecting blood and donors report any time during the center's working hours. The authors therefore concluded that periodic overload is unavoidable, especially at constant workforce size and variable numbers of donors reporting for donation at various hours. An overloaded system is usually associated with long waiting hours, and when the number of donors is small, the personnel is idle. Both conditions are considered disadvantageous, with negative impact on the whole process of blood/ blood component donation [19].

Good quality of the blood donation process is of utmost importance not only for the safety of donors, recipients and blood components but also because high quality service directly impacts on donor's satisfaction and reinforces his trust and loyalty. Melián Alzola and Martín Santana conducted research on a group of over 30,000 Spanish blood donors in order to determine the impact of the quality of the blood collection process on the level of donor satisfaction. They noted that the impact of donation process-quality is the subject of interest not only in the health care system, but also in the field of service and quality management. Some authors even suggest that the experience from customer service may support donor service and help blood centers provide excellent donor service and improve performance in the blood center. The authors also indicate that management of blood donation still remains largely unexplored due to the specific nature of the service. In contrast to traditional marketing where companies provide products or services, in blood donation, it is the donor who offers a "product", i.e. a voluntary blood donation. The "client" is therefore both the supplier of the "product" and the recipient of the service rendered by the blood donation center. Many donors perceive certain risks and inconveniences related to the donation process e.g. fear of the needle, time pressure, long distances from place of residence to donation center, all of which affect donor trust and readiness to donate. The authors point to the lack of trust in the blood service as the most likely reason for no intention to return (to donate). Pursuant to the above, the study proposes and validates a scale to measure the quality of donation process. Analysis of the results demonstrated how the quality of the donation process as a service affects three donor-related result indicators (satisfaction, trust and loyalty). Conclusions from this analysis may help to formulate recommendations for activities aimed at providing donors with positive experiences from visiting the blood donation center, and upgrading the effectiveness and efficiency of staff performance as reflected in donor retention, "recruitment" and development of targeted marketing strategies. As outcome of literature review and meetings with industry experts, Melián-Alzola and Martín-Santana designed a theoretical scale for measuring the quality of donation process. It is a four-structure dimension with its respective attributes: individual approach (e.g. staff training, a friendly, polite treatment), tan- 
gibles (e.g. cleanliness of the facilities and comfort), accessibility (easy access to the donation center, easy- to- find location) and post- donation actions (e.g. staff thanks donors after donation, feedback on clinical use of blood donation). As result of the above, it was concluded that the quality of the donation process must evaluate the different stages of donor experience at the donation center. It should also assess various issues, ranging from social and technical abilities of personnel to the design and state of facilities. The study confirmed the impact of service quality on donor satisfaction; each visit at the blood donation center may have either positive or negative impact on donor loyalty and his willingness to return. On the other hand, each donor visit is an opportunity for the blood donation center to increase his trust in the blood transfusion service. Better risk management, simplified procedures, professional image, kindness and empathy of the staff, cleanliness of the facilities and short waiting time may largely contribute to the quality of donor service and positive opinion of performance at the blood center. It is important for the blood donation center to win donor confidence and strengthen his loyalty, which should be the ultimate goal [20].

The level of donor satisfaction with the quality of the donation process was also assessed among Polish blood donors. The study was conducted in all 23 Polish RBTCs and comprised 4,000 completed questionnaires. Each questionnaire included 24 questions evaluating the manner of registration, medical examination/testing, collection of blood and blood components and indicating room for improvement in each category. The outcome showed that $90.7 \%$ of the respondents perceived the staff of the blood transfusion center as friendly and competent, $>70 \%$ assessed the service as efficient and professional, almost 50\% - reliable, and $28 \%$ - satisfactory. According to $83.5 \%$ of the respondents the donor service in RBTCs was very good, $16 \%$ - good, and $0.05 \%$ evaluated the service as satisfactory. Every third donor indicated that there should be space for children at the blood center, and $>50 \%$ would be pleased with feedback from RBTC after donation. In answer to the question: "What changes should be implemented to improve donor service?" almost $70 \%$ called for more stands for blood collection, $>50 \%$ - acceleration of medical examinations, $40 \%$ - shorter and simplified donor questionnaires. The indicated areas for improvement also included: shorter queues to donate (slightly $>30 \%$ ), more registration stands and better comfort (almost 30\%) as well as more doctors qualifying for donation $(>20 \%)$. The analy- sis shows that despite the overall positive opinion on the performance of blood donation centers, there are still areas related to donor service that require upgrading [21].

Melián Alzola and Martín Santana recommend that the blood transfusion centers express gratitude to the donor by sending thank-you letters or messages. It may also be advisable to acquaint donors with statistics and reports on the clinical use of their donations [20]. Polish blood donors also report the need for maintaining contact with RBTC. This indicates that such activities improve donor satisfaction and encourage them to return for subsequent donation [21].

Results of the presented analyses lead to the conclusion that individual RBTCs should be advised to prepare as many forecasts as possible, including donor availability for the coming months/years. Forecasting should be perceived as an important step in the process of decisionmaking. For the purpose of analysis and forecast retrospective data should be used, provided they are accessible and of adequate quality. It is also recommended to calculate the repeat donation rate for men and women in various age groups and to adapt marketing strategies to the situation in each RBTC. The eligibility and deferral coefficients in RBTCs should be calculated to find the reason for the significant differences observed nationwide. Bearing in mind that donor's satisfaction with his visit to the RBTC is the key element to the decision to donate again it seems advisable to make every possible effort to adapt the organization of work at blood transfusion center to the needs of the donor ("friendly" donation hours, schedules of mobile collection teams, etc.). It is equally important to make attempts at implementing modern technological solutions to help donors plan their visits to RBTCs e.g. a mobile application for donors. Computer systems and electronic devices are tools that open new pathways of reaching blood donors for more effective motivation for first time donation as well as donor retention.

\section{References}

1. Rosiek A, Tomaszewska A, Lachert E, et al. Działalność jednostek organizacyjnych służby krwi w Polsce w 2016 roku. J Transf Med. 2017; 10(4): 113-129.

2. Pogłód R, Rosiek A, Grabarczyk P, et al. Charakterystyka podstawowych wskaźników dotyczących krwiodawstwa i krwiolecznictwa w Europie - aktualne wyzwania i działania. J Transf Med. 2015; 8(2): 60-77.

3. Zapewnienie samowystarczalności RP w krew i jej składniki na lata 2015-2020 - Ministerstwo Zdrowia - Portal Gov. 
pl. Ministerstwo Zdrowia. https://www.gov.pl/web/zdrowie/ zapewnienie-samowystarczalnosci-rp-w-krew-i-jej-skladniki [dostęp z dnia 09.06.2021].

4. Samoliński B, Raciborski F, Lipiec A, et al. Epidemiologia chorób alergicznych w Polsce (ECAP). Alergol Pol - Pol J Allergol. 2014; 1(1): 10-18, doi: 10.1016/j.alergo.2014.03.008.

5. Absencja chorobowa w 2017 roku. Zakład Ubezpieczeń Społecznych; 2018.

6. Absencja chorobowa w 2018 roku. Zakład Ubezpieczeń Społecznych; 2019.

7. Findings from the Global Burden of Disease Study 2017. Institute for Health Metrics and Evaluation (IHME); 2018. http://www. healthdata.org/policy-report/findings-global-burden-disease-study-2017.

8. Wojtyniak B, Goryński P. Sytuacja zdrowotna ludności Polski i jej uwarunkowania. Narodowy Instytut Zdrowia Publicznego Państwowy Zakład Higieny; 2018.

9. Mikołowska A, Antoniewicz-Papis J. Retrospective analysis of selected aspects of public blood transfusion service as a starting point for assessment of the status of transfusion medicine in Poland Part 1: Demographic characteristics of the donor population reporting for blood donation. J Transf Med. 2020; 13(1): 67-103, doi: 10.5603/jtm.2020.0002.

10. Wittock N, Hustinx L, Bracke P, et al. Who donates? Cross-country and periodical variation in blood donor demographics in Europe between 1994 and 2014. Transfusion. 2017; 57(11): 2619-2628, doi: 10.1111/trf.14272, indexed in Pubmed: 28840944.

11. Yuan S, Chang S, Uyeno K, et al. Blood donation mobile applications: are donors ready? Transfusion. 2016; 56(3): 614-621, doi: 10.1111/trf.13387, indexed in Pubmed: 26545826.

12. Drozd W. Marketing społeczny w krwiodawstwie: jak rozmawiać z ludźmi, żeby oddawali krew. CeDeWu; 2016.

13. Lucas G, Win N, Calvert A, et al. Reducing the incidence of TRALI in the UK: the results of screening for donor leucocyte antibodies and the development of national guidelines. Vox Sang. 2012; 103(1): 10-17, doi: 10.1111/j.1423-0410.2011.01570.x, indexed in Pubmed: 22150747.

14. Roubinian N. TACO and TRALI: biology, risk factors, and prevention strategies. Hematology Am Soc Hematol Educ Program. 2018; 2018(1): 585-594, doi: 10.1182/asheducation-2018.1.585, indexed in Pubmed: 30570487.

15. Veld EH, Kort Wde, Merz EM. Determinants of blood donation willingness in the European Union: a cross-country perspective on perceived transfusion safety, concerns, and incentives. Transfusion. 2019; 59(4): 1273-1282, doi: 10.1111/trf.15209, indexed in Pubmed: 30811608.

16. Fosgaard T, Hansen L, Jacobsen C, et al. Can text messages save lives? A field experiment on blood donor motivation. Transfusion. 2020; 60(3): 460-465, doi: 10.1111/trf.15633, indexed in Pubmed: 31837032.

17. Martín-Santana JD, Beerli-Palacio A, Romero-Domínguez L. Recruitment strategies: non-donor segmentation based on intrinsic and extrinsic stimuli. Vox Sang. 2020; 115(1): 47-59, doi: 10.1111/vox.12858, indexed in Pubmed: 31696527.

18. Zapewnienie samowystarczalności RP w krew i jej składniki na lata 2021-2026 - Ministerstwo Zdrowia - Portal Gov.pl. Ministerstwo Zdrowia. https://www.gov.pl/web/zdrowie/zapewnienie-samowystarczalnosci-rzeczypospolitej-polskiej-w-krew-i-jej-skladniki-na-lata-2021-2026 [dostęp z dnia 09.06.2021].

19. Testik MC, Ozkaya BY, Aksu S, et al. Discovering blood donor arrival patterns using data mining: a method to investigate service quality at blood centers. J Med Syst. 2012; 36(2): 579-594, doi: 10.1007/s10916-010-9519-7, indexed in Pubmed: 20703678.

20. Melián-Alzola L, Martín-Santana J. Service quality in blood donation: satisfaction, trust and loyalty. Service Business. 2019; 14(1): 101-129, doi: 10.1007/s11628-019-00411-7.

21. Antoniewicz-Papis J, Lorek M, Rutkowska M, et al. Analiza badania ankietowego dawców krwi - „Satysfakcja krwiodawcy”. Acta Haematol Pol. 2015; 46: 24, doi: 10.1016/j.achaem.2015.07.043. 